Research Note

\title{
THE PACIFICATION OF THE FAVELAS: MEGA EVENTS, GLOBAL COMPETITIVENESS, AND THE NEUTRALIZATION OF MARGINALITY
}

\author{
SEBASTIAN SABORIO' \\ Department of Economics, Politics and Society. \\ University of Urbino, Italy
}

\begin{abstract}
Rio de Janeiro is preparing to host two major sporting events in the coming years: the 2014 FIFA World Football Cup and the 2016 Olympic Games. Local authorities are promoting these mega events as an opportunity to increase the global competitiveness of the city. But in order to attract private capital from the global economy it is not enough for Rio to showcase the city as capable of organizing and implementing these events. Rather, the authorities must also demonstrate that what has been considered one of the most dangerous cities in the world can now become a safe place for business. To do so, what has been promoted as a new model of 'community policing' the UPP (Pacifying Police Units) has been implemented since 2008 in 107 favelas. The majority of the favelas involved in the program are situated around the sites where these mega events will take place and around other wealthy areas of the city. This article analyses the relation between mega events, global competitiveness and the neutralization of local marginality.
\end{abstract}

\section{Résumé}

Rio de Janeiro se prépare à accueillir les plus grands événement sportifs des prochaines années: la coupe du monde de football en 2014 et les jeux olympiques en 2016. Les autorités locales valorisent ces événements mondiaux comme autant d'opportunités pour augmenter la compétitivité de la ville.

${ }^{1}$ Sebastian Saborio is a Sociology PhD candidate at the University of Urbino, Italy. His doctorate project is based on the pacification of the famous 'Favelas' in Rio de Janeiro. He examines the ways in which mega events, global competitiveness and the neutralization of urban marginality plays into the relationship between repression and assistance within the UPP (Pacifying Police Units) program, and its role in the reduction of urban violence and the transformation of police practices within poor communities. Sebastian Saborio est un aspirant au doctorat à l'université d'Urbino en Italie. Son projet de PHD se base sur la pacification des Favelas à Rio de Janeiro. Il examine quelle importance ont les événements mondiaux, la compétitivité internationale et la neutralisation de la marginalité urbaine dans la relation entre répression et assistance au sein du programme UPP (Pacifying Police Units), et son rôle dans la réduction de la violence urbaine et la transformation des pratiques policières dans les communautés pauvres. Contact: sebastian.saborio@gmail.com. 


\begin{abstract}
Cependant, il n'est pas suffisant pour attirer les capitaux privés de l'économie mondiale que Rio soit valorisée comme une ville capable d'organiser et de gérer ces événements. Les autorités doivent aussi démontrer que, ce qui auparavant était considéré comme une des plus dangereuses villes du monde, peut maintenant devenir un endroit sûr pour les entreprises. Dans ce but, l' UPP (Pacifying Police Units) a été mis en place en 2008 dans 107 favelas et est décrit comme le nouveau modèle de la police communitarian. La plupart des favelas intégrées dans le programme sont situées autour des lieux qui accueilleront les événements et dans d'autres endroits confortables de la ville. Pour cette raisons, cette article analyse les relations entre les événements mondiaux, la compétitivité mondiale et la neutralisation de la marginalité locale.
\end{abstract}

\title{
Key words
}

Pacification, Favelas, Rio de Janeiro, Mega events, Global competitiveness

\section{From the War on Drugs to the Armed Peace}

Since the beginning of the 20th century, the favelas in Rio Janeiro, or 'communities', as its residents prefer to call them, have been associated with marginality and violence (Valladares 2000). In the last thirty years in particular, the favelas have experienced confrontation among criminal rival gangs, such as the Comando Vermelho and Terceiro Comando which contend for the control of the drug market (Misse 1997). Furthermore, police brutality and corruption exacerbated the situation in the most vulnerable territories of the city that were, and in the most cases still are, controlled by oganized crime and by physical violence. ${ }^{2}$

The first Pacifying Police Unit (the Unidade de Policia Pacificadora or UPP) was launched in December $19^{\text {th }} 2008$ in the Santa Marta favela by the Security department of the State of Rio de Janeiro, with the support of the Municipality of Rio de Janeiro, the Federal government and private sector funds. At the moment, 30 different UPPs have pacified 'just' 107 of the almost 1000 favelas. To achieve this pacification, the favelas underwent what is essentially a military occupation. Each pacification starts with the arrival of the Special Police Operations Squad, otherwise known as 'BOPE', ${ }^{3}$ supported by the military naval and air forces, and finishes with the implementation of the UPP, which ensures the constant, pervading presence of the Military Police within the communities.

Before the creation of UPPs, smaller security programs like the Integrated Centre of Community Police in 1983 and the Special Areas Policing Group of Rio de Janeiro's

\footnotetext{
2"Since the inception of the large-scale drug trade, violence has increased over 54 percent" (McRoskey 2010, 95).

${ }^{3}$ In Portuguese BOPE (Batalhão de Operações Policiais Especiais). This squad became globally famous thanks to the movie "Elite Squad" (2007). See "Giamberardino, André Ribeiro . Letture e Dibattiti: Tropa de Elite, Regia di Jose Padilha. Ius17@unibo.it: Studi e Materiali di Diritto Penale, v. 2, p. 541-544, 2009.
} 
Military police force in 2000, had been advertised by the Security Department as community policing programmes (Cardoso 2011). However, the UPP project was intended to be a "new model of public security that bridges the gap between population and police". ${ }^{4}$ Yet, Rio de Janeiro is used to such declarations of police innovation. Thus, Frühling has documented how "since the 1990s, every proclamation for police reform in Latin America led to the launching of a community policing programme designed to improve police community relations" $(2012,76)$. These kinds of programmes represent an easy way to create a political consensus between the local population and, in Rio de Janeiro's case, international public opinion. Scholars (Barbosa 2012, Cano 2012, Fleury 2012, Machado da Silva 2010) have criticized the idea that the UPP is a community policing programme, arguing that it fails to meet the majority of criteria that characterise community policing philosophy, such as developing strong relationships with the community, ongoing consultation, dealing with concrete security issues and being proactive rather than reactive (Frühling 2012, 78). Principally, as Barbosa (2012) pointed out, there is no active engagement on behalf of the residents in maintaining the 'security and order' imposed by the arrival of the BOPE nor is the community actively involved in the subsequent UPP patrolling of the territory. In fact, the UPP implements what appears to be a military operation (Yutzy 2012).

Armed control of the occupied territories is done little different to the control operated by the drug gangsters (Misse 2011), in fact the Pacification Police's first objective is to affirm the presence of the State in the favelas. Hence the first step is the presence of police officers patrolling the streets on foot and in vehicles, acting promptly to impose the laws and The Law. The Governor of the State of Rio de Janeiro, Sergio Cabral, used explicitly military terms borrowed from the colonial matrix to define his project of neutralization of local marginality: pacification. By using the term 'pacification' and by promoting the occupation of the favelas as an important step forward in the war on drugs, Cabral disclosed what the mainstream Brazilian media tried to hide: that pacification was to be an act of war, dressed up as peace (Neocleous 2010, 14). The declaration that peace has to be brought inside the favelas and the application of the same logic that sees the favelas as the enemy in the 'war on drugs' was a communicative tactic used to legitimize the militarization of civilian territories. At a rhetorical level, the description of it as a war and the criminalization of internal groups of citizens as part of this war was a way of managing public opinion towards accepting the state's repression of both the working and underclass that compose the communities in question.

The stated objective of the pacification of the favelas is to take back the control of these territories by expelling or disarming traffic dealers, in order to implement, with parallel programs, social services and economic activities that are supposed to benefit the most disadvantaged population of the city. Targeting traffic dealers as the only dangerous

\footnotetext{
${ }^{4}$ http://upprj.com/wp/?page_id=20 (literal translation by the Author).
} 
category of the favelas, the rhetoric partially overcame the paradoxical stereotype that considered the poor as a dangerous class when living in favelas but not whilst working in the less guaranteed and worst paid jobs inside the 'legal city'. This paradox enabled the economic forces to exploit an important labour resource without requiring the State to provide adequate social services and infrastructures in the favelas. Yet to understand the real causes of the pacification of the favelas we need to go beyond the mainstream rhetoric. As Rigakos explains, the term pacification is less ubiquitous than the term security, and it allows us to ask, "Who is being pacified? Why are they being pacified and why are they resisting?". In other words, it allows us to ask: "What are the real objectives of this pacification project?" (Rigakos 2011, 63).

Our starting point is the fact that the pacification process started around the time when Rio de Janeiro was selected as the host city of two of the major sporting events of the world. The city was selected as the host of the FIFA (Fédération Internationale de Football Association) World Cup on 30 October 2007 and as the host of the 2016 summer Olympic games on 2 October 2009; the pacification process started on 19 December 2008. In this context, the decision to 'bring peace' to the favelas coincided with city administrators' desire to uphold promises given to the IOC (International Olympic Committee) and to the FIFA regarding the improvement of security in certain areas of the city. The majority of the pacified favelas are in fact not located within the metropolitan areas that have a higher violent death rate. Most of the UPPs are located in the southern tier of the city or around the famous Maracanã stadium, creating an 'urban security belt' around the venues where the FIFA World Cup and the Olympic Games are to be held. ${ }^{5}$ The remaining favelas located near sporting venues, major tourist attractions and access points to the new public transport system that is being constructed, are on the list of areas to be formally pacified as part of the program.

The pacification process itself is intended to ensure the actual physical safety of visitors, such as occurred at the South African 2010 FIFA World cup where sporting venues and other leisure areas like the 'fan parks' (Giulianotti \& Klauser 2010), housed tourists in highly militarized and surveyed perimeters of the city, as Christopher McMichael has discussed elsewhere in this volume. In the first year of Sergio Cabral's administration, the 2007 Pan American Games provided Rio with an opportunity to experiment with security techniques during sport mega events. On that occasion, a temporary security wall was erected around the sporting venues (Curi 2011) and the Alemão Favela complex was occupied by the police and military in an operation that resulted in the death of 19 civilians (Freeman 2012). Rather than security walls as such,

\footnotetext{
${ }^{5}$ Unlike South African cities, where the "concentration of violent crime in poor, black townships and informal settlements" (See Christopher McMichael in this special issue) were located far away from the Game's venues, some of the Rio's favelas are in the same areas where the FIFAifa World Cup and the Olympic Games will be held.
} 
Rio de Janeiro plans to spend around US \$100 million in CCTV cameras for both events, and for the 2014 FIFA World Cup alone over 53.000 new police agents will be enlisted in Brazil's Special Task Force (Dossiê do Comitê Popular da Copa e Olimpíadas do Rio de Janeiro 2012). Moreover, it is highly likely that the favelas will be further militarized as the events get closer, and certainly during the events themselves.

\section{Pacification: A Consensus Machine}

The actual pacification undertaken by police is not just oriented to securitizing the venues hosting such events, but also to creating a consensus between internal elites and international public opinion. Mainstream local media has almost unanimously demonstrated an 'uncritical enthusiasm' (Machado da Silva 2010) for the UPP project, as it has been presented and thus welcomed as the solution for urban violence. The rhetoric of authorities used to legitimatize the pacification process is different, however, when directed to a local audience compared to an international one. For Rio de Janeiro voters, the success of a mega event cannot be considered a priority in comparison to public safety and social wellbeing. So, at a local level, the UPP will gain public approval as long as they secure elite residential areas and promise to improve the conditions of life of the dwellers of the favelas. At the international level, in contrast, the issue is presented as the security of visitors, behind which lies the reputation of the city itself. In other words, whereas in Brazil the pacification of favelas is not presented in terms of its necessity for the FIFA World Cup and Olympic Games, at the international level it is. Hence, for example, on the Portuguese version of the UPP web page (http://www.upprj.com/) the official Olympic Games logo does not appear, whereas on the English version web page (http://www.upprj.com/index.php/as_upps_us) it did -this has since been changed -underlining the links between the UPP and the staging of the Olympics. Furthermore, under the 'Frequently Asked Questions' (FAQ) section of the Olympic Games web page one finds the question "how will security be ensured at the Games?". The answer offered is that "the general population is already reaping the benefits of the project of the deployed Rio de Janeiro Pacifying Police Units (UPP) based on responsible and careful planning" (rio2016.com, my italics). The relationship of the UPPs to mega events is better acknowledged in the international press than in the Brazil media. Indeed, on the IOC international website, the UPP is acknowledged as part of a 'responsible' process of 'careful planning' as we have just seen.

For the city to demonstrate 'responsible and careful planning', questions about the UPP's violence and repression are ignored. Instead, the pacification of the favelas is presented as improving human rights and general levels of security, to an international audience that is better acquainted with Rio's long history of police corruption and brutality. Yet the UPP's provide another important function, which is to delegitimize 
political protest. If we consider that mega events are "important because they provide a political opportunity structure unlike any other on the world stage" (Cottrell \& Nelson 2011, 732), then in the case of Brazil the opportunity to delegitimize political protests has been seized. Protest against the security measures themselves is presented as unnecessary or anachronistic. Insofar as pacification is successful, 'protest' is redundant; all that matters is the 'security' of the 'community'. Moreover, even though episodes of police violence and corruption during the pacification of the favelas have undermined the 'community-friendly' approach of the UPP, it is still promoted as part of the mega events social legacy for the entire city.

The idea that mega events are an opportunity to improve social conditions is also fundamental to legitimizing the huge amount of public expenditure, that, as many studies demonstrate, do not have a positive economic impact for the hosting cities (Szymanski $2011,91)$. In particular, there is no evidence of any economic benefit for the poorest groups of citizens (Minnaert 2012).

This creation of a consensus around the mega-event and the necessity of pacification is especially important given the relative absence of democratic decisionmaking with respect to public spending connected with the Olympics and related 'security' ventures and expenses. The APO (Public Olympic Authority) is an extragovernmental institution, formed as a joint-venture between the Federal Government, the State and the Municipality of Rio de Janeiro. The APO will control a R\$30billion budget, which is expected to be surpassed. Further, it has the authority to acquire land through eminent domain and acts as the central coordinating authority for Olympic security (Gaffney 2010, 25). The Olympic Plan, which will shape the urban infrastructure and involves, as noted, significant public funds, was formulated by the unelected Brazilian Olympic Committee and the APO, excluding institutional decision-making mechanisms that already exist within Brazilian society (Vainer 2011) and largely bypassing any democratic discussion. Although $90 \%$ of the Olympic and FIFA World Cup funds in Rio de Janeiro come from the public sector (Dossiê do Comitê Popular da Copa e Olimpíadas do Rio de Janeiro 2012), profits remain in the hands of international sport institutions and private investors. Why, then, did the city decide to bid and stage these mega events?

Mega events put Rio de Janeiro on the map of global, competitive cities. Hence, the staging of the event can be understood as an effort to signal Rio's attractiveness to foreign investors. But, according to the definition of 'sustainable competitiveness' of the World Economic Forum (Schwab 2012), the city of Rio does not, in fact, have a sustainable, competitive business plan. Economic, social, and environmental factors are never equally balanced when attempting to meet the requirements of these mega events. The need to achieve the general infrastructural requirements demanded by the OIC and FIFA places the interests of capital in the foreground, without serious consideration for the real needs of the local population. The 'Legacy Plan' for the FIFA World Cup and the Olympics Games proclaims that mega events are aimed at creating "a better Rio for its 
inhabitants, by promoting structural changes in the transportation system, urban infrastructures, environment and social development (Costa 2012,)" ${ }^{\prime 6}$, but it is rare for any such mega event to leave such a legacy. (Minnaert 2012). Since improved public housing, transportation, sanitation, education and public space, are rarely genuinely considered in the plans for such events (Bienenstein et al. 2010, 8), it is perhaps not surprising that improved local welfare is rarely the outcome of staging such global sporting events. However, there are benefits for capital and for 'security', by which I mean not actually improved safety for the vast majority, and especially the poorest, but the pacification of potentially rebellious subaltern classes and groups.

\section{Compete Globally, Lose Locally: Mega Events and the Securitization of Private Capital}

As noted, central to the ways in which political authorities and the mainstream media talk about such mega events is the idea that they will enhance Rio de Janeiro's global competitiveness by creating the necessary conditions for investment. However, to be accepted by the population, the competition-oriented strategy of the city is presented as indispensable to the planning and implementation of an urban renovation to solve certain structural problems. The current urban planning objectives are based on the desire to integrate poorer communities into the urban system through the urbanization and pacification of some favelas, in order to recover urban sites that have been ghettoized,and improving the public transport system. . Yet, the emphasis has not been on cooperating to fairly allocate existing resources. Instead, the promoters of these mega events have fostered the idea that sites should compete in a 'war of cities', in an effort to attract foreign capital on a worldwide market (Arantes et al. 2002).

Towards 2016: A More Integrated and Competitive Rio is the title of the Municipality's Strategic Plan for 2009-2012. It clearly outlines how, until the end of the Olympic Games in 2016, a mega event-oriented strategy will support the city's competitiveness. Under this prospect, mega events are promoted as opportunities for cities to showcase their material and symbolic resources and so attract capital flows from the global market. Rio is to realise its role as the 'Marvellous City', as the city now calls itself in an aggressive branding campaign (Jaguaribe 2012). This branding aims to sell an image of the city as a fertile, productive site, where investors can find optimal conditions to develop their businesses. Just as with any other product in the market, the city is being advertised for its positive features, both real and purposely built to attract tourists, entrepreneurs, real estate developers and multinational corporations. This emphasis on foreign investment means that the needs of local populations are at best secondary considerations, promoted only if compatible with the needs of both domestic capital and foreign investors.

\footnotetext{
${ }^{6}$ My translation.
} 
The Carioca Carnival and samba culture, together with other traditional tourist attractions such as the world famous beaches, have always allowed Rio de Janeiro to compete in the global tourist market. However, the exponential increase in urban violence in the last thirty years or so has progressively curbed the city's appeal to foreign visitors. The UPP's project is helping to change the perception of tourists by showing Rio de Janeiro, or at least the gentrified southern tier where the mega events will be hosted, as a safe place to visit and invest. By taking advantage of the 'touristification' of the favelas (Russo 2012), the pacification process is slowly transforming and making urban spaces previously considered as 'no-go areas' accessible for tourists and middle-class individuals. Tourism has thus increased within the pacified favelas. Indeed, it can be argued that befitting a purely voyeuristic spectacle of urban poverty, the favelas are now offering tourists the spectacle of pacification itself. .

Yet tourism plays only one role in the city's strategy of becoming more 'business friendly'. To attract capital, mega events facilitate deregulation policies based on a supposed demand for labour flexibility and to neutralize other restrictions on accumulation. Thus the successful implementation of the mega events helps give legal form to what otherwise might not have a legal form (Agamben 2003, 10), allowing the state to enact ad hoc legislations and special authorizations that facilitate accumulation (Vainer 2011) - but to do so in the name of Olympic pride rather than explicitly 'for businesses'. Witness, for example, the General Law of the World Cup, effective from May 2012, which privileges the FIFA with commercial advantages in Brazil, so disregarding fundamental rights protected by existing legislation, such as the Consumers Defence Code (Costa 2011).

Capitalist accumulation is thus facilitated given the supposed urgency of implementation, due to the shortened time frames of mega-events. At the same time, urban transformation is very much part of an existing strategy of capitalist accumulation. In this way, although mega events are not the original causes of the 'depredatory planning' implemented in the Global South (Graham 2012), they certainly accelerate and legitimate it. In fact, for countries of the Global South such as Brazil and South Africa "hosting a mega event is often first and foremost a political mega project, undertaken by elites to fortify the State and to engineer societal transformation" (Cornelissen 201, 3222). Mega events thus rhetorically legitimate the forced removal of some poor communities with neither fair compensation or decent reallocation (Araujo de Assumpção \& Schramm 2012), the securitization and 'beautification' of other poor communities, and further real estate speculation in increasingly gentrified urban areas (as Christopher McMichael also shows in this volume).

For the World Cup in 2014 and the Olympic Games in 2016 in Brazil, more than 170,000 Brazilian families have already had their housing rights violated. Forced evictions had been carried out, counter to Brazilian and international human rights law, in order 
to build the new stadiums and transport infrastructure and supposedly guarantee security in the areas of the mega events in question (Dossiê da Articulação Nacional dos Comitês Populares da Copa 2012). However, Davis (2011) points out that forced evictions occurring before a mega event usually continue afterwards. Moreover, similar illegal removals also occur in cities that have entered a bid for a mega event but have not been awarded with hosting it. This allows us to see the extent to which mega events are an instrumental tool to reconstitute the urban landscape around the logic of security and the needs of capital. The process of 'urban growth' which we are told is necessary to host any mega events, absorbs the surplus produced by capitalism, guarantees high profits to private industrial corporations and entrenches new security measures (Harvey 2012). The improvements for high-income populations are dependent on the securitization of poor communities, which is a way of saying that the wealth of one class is dependent on the pacification of another.

In 2011, the real estate market in the city experienced a $44 \%$ boom compared to 2010 (Rolnik 2012). In particular, the increase affected areas immediately adjacent to the pacified favelas. For example, some properties before pacification cost around $\mathrm{R} \$ 30,000$, but after pacification were selling for $\mathrm{R} \$ 200,000$ or more (Freeman 2012). Moreover, in May 2010, only a year and a half after the implementation of the first UPP, real estate value increased by $400 \%$ in the favelas involved in the pacification project. As a consequence, rent inflation is forcing the poorest residents to abandon their homes. Besides, current land tenure regularisation policies mean that owners with financial difficulties may be relatively easily "persuaded to trade in that asset for a cash payment at a relatively low price" (Harvey 2012, 20). Harvey has predicted that "if present trends continue, within fifteen years all those hillsides now occupied by the favelas will be covered by high-rise condominiums with fabulous views over Rio's bay, while the erstwhile favela-dwellers will have been filtered off to live in some remote periphery".

The outcome is that the existing differences between poorest and wealthiest urban areas are exacerbated. When the city wakes up from its Olympic dream, its class divisions will be even more apparent, written into the urban infrastructure. A higher number of global citizens will visit, inhabit and invest in the city, while the working class will struggle with labour flexibility, residential uncertainty and violent repression at the margins of these urban centres.

\section{Pacification: An Incomplete Project}

The pacification of the favelas is part of the mega events legacy. In practice, it aims not only to mitigate urban violence but also to allow the state to implement social and infrastructural changes. Contrary to official claims, however, as soon as a UPP is

established in a community, social improvements are disregarded as a main priority. The 
arrival of the Pacification units does not significantly change the classical governmental approach in relation to the favelas. The historic uncertainty of the juridical situation of such informal settlements, stigmatized as loci of urban violence even when they experience urbanization, legalization and securitization processes, is used to justify the lack of public investment (Gonçalves 2006). Even José Mariano Beltrame, the head of the Security department of the State of Rio de Janeiro, has noted the lack of real investment in social programs and failure to implement basic services such as garbage collection (see Elenilce Bottari, Liane Gonçalves, 2011).

Here we should note the role of the UPP Social, a parallel program to the UPP. The former, managed by the institute responsible for municipal urban planning (Pereira Passos Institute), promotes a proactive dialogue between different stakeholders from government, entrepreneurs and civil society. However, as Fleury (2012) outlines, besides being implemented in the favelas with a remarkable delay - in some cases three years after the initial pacification process - it is not clear which actions have been undertaken to effectively implement new social policies. As a result, no significant policies in healthcare, education or concerning basic needs have followed the implementation of the UPP (Vieira da Cunha 2012). Instead, pacification is used to achieve a beautification strategy of the favelas visible from the mega events sceneries but not to bring about meaningful improvements in social welfare.

Pacification partially integrates the favelas into the urban system, but seeking to incorporate them into the mainstream market economy. Utilities such as electrical power, water and pay-TV that were previously supplied by illegal connections are now being managed by regular private companies. Beyond the obvious economic profits for service providers, the population of the favelas is reaping some benefits from the regularization process. For example, Light, a private power company, is substituting dangerous electrical installations with safer ones (Vieira da Cunha \& Mello 2011). Residents that can afford price increases may be happy to pay for more reliable and safer services. But for the most needy segments of the pacified communities, higher bills are forcing them to seek dwellings in other cheaper localities, as we have noted, where they find the same inadequate living conditions they left.

It is important to recognize that by substituting armed gangs with less violent police control, the government is transforming each favela in important ways. However, the tactic was driven first and foremost by the effort to recover and re-occupy strategically important urban areas in order to reassure domestic capital and attract foreign investment; the safety and needs of the favela populations have always been secondary to these other considerations. The occupation of these favelas is allowing Rio de Janeiro to enhance its global competitiveness by curbing street criminality in the surrounding wellto-do areas that receive global investments and are of the most interest to capital. Moreover, the presence of police in the favelas neutralizes the marginal population by 
forcing it to accept market rules in their communities; the favelas are policed reserve armies of labour, sometimes the proletariat, but these populations are not allowed to exist as decommodified spaces of community solidarity.

When Neocleous (2011) reconstructs the origin and evolution of the term pacification, he explains that the destruction of an established social system and the consequent reconstruction of what is promised to be a 'brighter and nicer new life', is put into place to secure the capitalist accumulation process. To induce a pacified population to accept the new order, Neocleous continues, the state uses a careful combination of 'force and politics', of repression and ideological indoctrination. If the pacification strategy is successful, then alongside strategies of control one sees the construction of market relationships and new forms of exploitation. In one sense, this is what is happening in the favelas of Rio de Janeiro. Yet, in another way, this is not being fully accomplished. For no 'balance' between force and politics, repression and indoctrination, is necessary if there is no opposing force to jeopardize the global competitive strategy adopted by the city. To put it another way, we must always ask where is the possibility of resistance?

Community organizations in Rio are already reacting against the price of an imposed peace. Some of the existing associations inside the communities have joined forces by creating networks in order to implement preventive actions against police brutality and to fight for a 'brighter and nicer new life' against and beyond the UPP forces.

In Santa Marta Favela the association Visão da favela (Favela's Vision) with other associations and NGOs such as Justiça Global (Global Justice) created a handbook to distribute to residents that clearly explains their rights related to the police presence in their community. The same is currently being carried out in other favelas that have not yet been pacified, such as the Maré favela, where a civil society campaign is preparing residents for the arrival of a new UPP, by sharing strategies about how to avoid and fight police brutality. Networks such as Rede Contra a Violência (Network Against Violence) and the Favela Favela Não Se Cala (The favela does not shut up) struggle against the police repression and forced removals.

"Peace without voice is not peace, it's fear!" is one of the most quoted mottos in the anti-UPP demonstrations. The possibility of improving social conditions inside the favelas increases when residents take advantage of the political opportunity structure produced by the mega events and collaborate with networks like the Comitê Popular da Copa e Olimpiadas do Rio de Janeiro, to challenge the unequal benefits of the Olympics and to call for peace rather than pacification. For instance, this Committee is a civil society network that denounces the human rights violations related to the organization of the mega event and to challenge the unfair redistribution of social and economic benefits associated with them. Indeed, a major challenge for the UPP is to contain the daily forms of micro-resistance of favela dwellers (Cano 2012) and the spontaneous riots after the 
pacifying forces have killed dwellers of the occupied territories.

This struggle against pacification and the UPP has not been easy, not least because it is inevitably also a struggle against the mainstream media and public opinion. But it does suggest that pacification is an incomplete project. As long as local residents, often the poorest and more vulnerable, refuse to accept living in armed peace as normal or even necessary, there will always be the possibility of resistance.

\section{References}

Agamben, Giorgio. 2003. Stato di eccezione. Torino: Bollati Boringhieri.

Arantes, Otília- Vainer, Carlos and Maricato, Ermínia. 2002. A cidade do pensamento único. Desmanchando consensos. $3^{\circ}$ ed. Petrópolis: Editora Vozes.

Araujo de Assumpção, Erick L. and Schramm, Fermin R. 2012. 'Elementos para uma análise bioética das transformações urbanas'. Revista bioética, 20: 106-118.

Barbosa, Antonio R. 2012. 'Considerações introdutórias sobre territorialidade e mercado na conformação das Unidades de Polícia Pacificadora no Rio de Janeiro'. Revista Brasileira de Segurança Pública, 6: 256-265.

Bienenstein, Glauco- Sánchez, Fernanda and Mascarenhas, Gilmar. 2010. 'The 2016 Olympiad in Rio de Janeiro: Who Can/Could/will Beat Whom?' (paper presented at AAG Annual Meeting, Washington D.C, April 14/14, 2010).

Bottari, Elenilce and Gonçalves, Liane. 2011. 'Beltrame quer pressa em investimentos sociais pós-UPPs: Nada sobrevive só com segurança'. Jornal O Globo, 28 May 2011. http://oglobo.globo.com/rio/beltrame-quer-pressa-em-investimentossociais-pos-upps-nada-sobrevive-so-com-seguranca-2764060.

Cano, Ignácio. 2012. 'Os donos do morro: Uma avaliação exploratória do impacto das Unidades de Polícia Pacificadora (UPPs) no Rio de Janeiro'. LAV/UERJ and Fórum Brasileiro de Segurança Pública.

Cardoso, Marcus. 2011. 'Obstáculos para o sucesso de projetos de policiamento comunitário'. (paper presented at the XI Congresso Luso Brasileiro de Ciencias Socias. Diversidades e (Des)Igualdades, Bahia 7-10 August 2011). 
Comissão de Turismo e Desporto. 2012. 'Ciclo Olímpico Brasileiro tem que deixar legados sócios educacionais'. Conselho Federal de Educação Física, 24 September 2012. http://www.confef.org.br/extra/clipping/view.asp?id=453.

Comitê Popular da Copa e Olimpíadas do Rio de Janeiro. 2012. 'Dossiê do Comitê Popular da Copa e Olimpíadas do Rio de Janeiro: Megaeventos e violações dos direitos humanos no de Janeiro'. http://www.agb.org.br/documentos/dossic3aa-megaeventos-e-violac3a7c3b5esdos-direitos-humanos-no-rio-de-janeiro.pdf.

Comitês Populares da Copa. 2011. 'Dossiê da Articulação Nacional dos Comitês Populares da Copa'. http://direitoamoradia.org/?p=4639\&lang=pt.

Cornelissen, Scarlett. 2011. 'Mega Event Securitisation in a Third World Setting'. Urban Studies, 48: 3221-3240.

Costa, Giuliana. 2012. 'Rio de Janeiro città dei mega eventi sportivi: progetti, politiche urbane e impatti sociali'. Territorio, 1.

Cottrell, M. Patrick and Nelson, Travis. 2011. 'Not just the Games? Power, protest and politics at the Olympics'. European Journal of International Relations, 17: 729753.

Curi, Martin. 2011. 'The Pan American Games in Rio de Janeiro 2007: Consequences of a sport mega-event on a BRIC country'. International Review for the Sociology of Sport, 46: 140-156.

Davis, Lisa K. 2011. 'International Events and Mass Evictions: A Longer View'. International Journal of Urban and Regional Research, 53: 582-599.

Fleury, Sonia. 2012. 'Militarização do social como estratégia de integração - o caso da UPP do Santa Marta'. Sociologias, 14:194-222.

Freeman, James. 2012. 'Neoliberal accumulation strategies and the visible hand of police pacification in Rio de Janeiro’. Revista de Estudos Universitários, 38.1.

Frühling, Hugo. 2012. 'A realistic look at Latin American community policing programmes'. Policing and Society: An International Journal of Research and Policy, Vol 22.1: 76-88. 
Gaffney, Christopher. 2010. 'Mega-events and socio-spatial dynamics in Rio de Janeiro, 1919-2016’. Journal of Latin American Geography, 9: 7-29.

Giulianotti, Richard and Klauser, Francisco. 2010. 'Security Governance and Sport Megaevents: Toward an Interdisciplinary Research Agenda'. Journal of Sport and Social Issues, 34: 49-61.

Graham, Stephen. 2012. 'When Life Itself is War: On the Urbanization of Military and Security Doctrine'. International Journal of Urban and Regional Research, 36: 136-155.

Harvey, David. 2013. Rebel Cities: From the Right to the City to the Urban Revolution. London-New York: Verso.

Imóveis em favelas com UPP sobem até 400\%. Jornal O Globo, 29 May 2010. http://oglobo.globo.com/rio/imoveis-em-favelas-com-upp-sobem-ate-4003001504.

Jaguaribe, Beatriz. 2012. 'Imaginando a 'cidade maravilhosa': modernidade, espetáculo e espaços urbanos'. Revista Famecos: mídia, cultura e tecnologia, 18: 327-347.

Machado da Silva, Luiz. A. 2010. 'Afinal, qual é a das UPPs?. Río de Janeiro'. www. observatoriodasmetropoles. ufrj. br.

McRoskey, Samantha R. 2010. 'Security and the Olympic Games: Making Rio an Example'. Yale Journal of International Affairs, 5.2.

Minnaert, Lynn. 2012. 'An Olympic legacy for all? The non-infrastructural outcomes of the Olympic Games for socially excluded groups (Atlanta 1996eBeijing 2008)'. Tourism Management, 33: 361-370.

Misse, Michel. 1997. 'As ligações perigosas mercados ilegais, narcotráfico e violência no Rio’. Contemporaneidade e Educação, Ano 2:1.

Misse, Michel. 2011. 'Os rearranjos de poder no Rio de Janeiro'. Le Monde Diplomatique Brasil. April 2011.

Neocleous, Mark and Rigakos, George. 2011. 'Anti-Security: A Declaration'. In AntiSecurity, edited by Mark Neocleous and George S. Rigakos. Ottawa: Red Quill Press. 
Neocleous, Mark. 2011. 'A Brighter and Nicer New Life: Security as Pacification'. Social Legal Studies, 20: 191-208.

Neocleous, Mark. 2010. 'War as peace, peace as pacification'. Radical Philosophy, 159: 817.

Prefeitura do rio de janeiro. 'Plano estratégico da prefeitura do rio de janeiro 2009 - 20 1 2: Pós 2016, O rio mas integrado e competitivo'. http://www.proppi.uff.br/turismo/sites/default/files/planejamento_estrategico_rj1_0.pdf.

Ranci, Costanzo. 2011. 'Competitiveness and Social Cohesion in Western European Cities'. Urban Studies, 48: 2789-2804.

Ribeiro Giamberardino, André. 2009. 'Letture e Dibattiti: Tropa de Elite, Regia di Jose Padilha. Ius17@unibo.it'. Studi e Materiali di Diritto Penale, 2: 541-544.

Rio 2016. 'How will security be assured at Games time?'. http://rio2016.com/en/how-willsecurity-be-assured-at-games-time.

Rolnik, Raquel. 2012. 'Rio de Janeiro: campeão olímpico em preços de imóveis?', 2 August. 2012. http://raquelrolnik.wordpress.com/2012/08/02/rio-de-janeirocampeao-olimpico-em-precos-de-imoveis/.

Russo, Antonio Paolo. 2012. 'Branding Brazilian slums through «freeware» cultural production: the case of Rio de Janeiro' In International Place Branding Yearbook 2012: Managing Smart Growth and Sustainability, (ed) Go, F., and Govers, R. Basingstoke and New York: Palgrave Macmillan.

Schwab, Klaus. 2012. 'The Global Competitiveness Report 2011-2012'.World Economic Forum. http://www3.weforum.org/docs/WEF_GCR_Report_2011-12.pdf.

Smith, Neil. 1996. The New Urban Frontier: Gentrification and the Revanchist City. New York: Routledge.

Soares Gonçalves, Rafael. 2006. A política, o direito e as favelas do Rio De Janeiro: Um breve olhar histórico. Journal des Anthropologues.104-105.

Szymanski, Stefan. 2011. 'About Winning: The Political Economy of Awarding the World 
Cup and the Olympic Games'. SAIS Review, 31: 87-97.

Vainer, Carlos. 2011. 'Cidade de Exceção: reflexões a partir do Rio de Janeiro'. http://www.opp.ufc.br/urbano04.pdf.

Valladares, Licia. 2000. 'A Gênese Da Favela Carioca. A Produção Anterior Às Ciências Sociais'. Revista Brasileira De Ciências Sociais, 15.44: 5-34.

Vieira da Cunha, Neiva and Da Silva Mello, Marco Antonio. 2011. 'Novos conflitos na cidade: A UPP e o processo de urbanização na favela'. Dilemas Revista de estudos de conflito e controle social, 3.4 .

Vieira da Cunha, Neiva. 2012. 'Vivienda popular y seguridad pública: el proceso de pacificación en las favelas de Río de Janeiro’. In Dimensiones del hábitat popular latinoamericano. FLACSO Ecuador: Instituto de la Ciudad CLACSO.

Yutzy, Chris. 2012. 'Increased state presence through the Unidade de Polícia Pacificadora in Santa Marta, Rio de Janeiro: the creation of the city's theme park and resulting social issues'. Revista de Estudos Universitários, 38: 127-146. 